\title{
APLIKASI OLAP PROFIL MAHASISWA DAN LULUSAN
}

\author{
Arie Nugroho \\ Fakultas Teknik, Program Studi Sistem Informasi \\ Universitas Nusantara PGRI Kediri \\ Email: arienugroho@unpkediri.ac.id
}

\begin{abstract}
ABSTRAK
Profil mahasiswa dan lulusan adalah salah satu data yang sangat dibutuhkan suatu universitas dalam proses akreditasi. Dengan data tersebut univeristas dapat mengetahui informasi tentang kondisi akademik mahasiswa. Data-data yang bisa didapat adalah jumlah mahasiswa, lulusan dan kelompok mahasiswa berdasarkan Indeks Prestasi komulatif (IPK) dalam periode tertentu. Data mahasiswa yang belum terintegrasi menyebabkan kesulitan dalam menampilkan data - data yang dibutuhkan, sehingga dibutuhkan alat bantu berupa aplikasi OLAP profil mahasiswa dan lulusan dengan data-data yang diperoleh dari program studi. Data - data yang digunakan diambil dari Program Studi Sistem Informasi Fakultas Teknik Universitas Nusantara PGRI Kediri. Pada penelitian ini dilakukan tahap analisa dan pemecahan masalah, perancangan tampilan aplikasi,tahap uji coba aplikasi dan implementasi. Hasil dari penelitian ini adalah aplikasi OLAP untuk menampilkan prosentase IPK lulusan berdasarkan range tertentu dan menampilkan IPK minimum, rata-rata dan maksimum.
\end{abstract}

Kata kunci: $O L A P$, profil, mahasiswa, lulusan, IPK.

\begin{abstract}
Profile of students and graduates is one of the data needed by a university in the accreditation process. With these data universities can find information about student academic conditions. The data that can be obtained is the number of students, graduates and student groups based on the Com-pative Achievement Index (GPA) within a certain period. Student data's that has not been integrated causing difficulties in displaying the required data's, so it takes tools in the form of OLAP application of student profiles and graduates with data's obtained from the study program. In this research is done analysis and problem solving phase, design of application display, application test phase and implementation. The result of this research is OLAP application to show the percentage of GPA of graduates based on certain range and display minimum GPA, average and maximum.
\end{abstract}

Keywords: OLAP, profile, students, graduates.

\section{PENDAHULUAN}

Akreditasi perguruan tinggi digunakan untuk mengetahui standart mutu perguruan tinggi. Akreditasi perguruan tinggi diselenggarakan oleh Badan Akreditasi Nasional Perguruan Tinggi (BAN-PT). Dalam proses akreditasi perguruan tinggi diharuskan mengisi borang akreditasi sesuai dengan institusi yang akan diajukan dalamn proses akreditasi. Berdasarkan pengumuman no : 609/BAN-PT/Edaran/III/2009 perihal Pemberlakuan Borang Baru untuk Akreditasi Program Studi Sarjana. Borang akreditasi program studi mempunyai tujuh standart yang harus dipenuhi. Standart satu membahas tentang visi, misi, tujuan dan sasaran, serta strategi pencapaian. Standart dua membahas tentang tata pamong, kepemimpinan, sistem pengelolaan, dan penjaminan mutu. Standart tiga membahas tentang mahasiswa dan lulusan. Standart empat membahas tentang sumber daya manusia Standart lima membahas tentang kurikulum, pembelajaran, dan suasana akademik. Standart enam membahas tentang pembiayaan, sarana dan prasarana, serta sistem informasi. Standart tujuh membahas tentang penelitian, pelayanan/pengabdian kepada masyarakat, dan kerjasama.

Dalam penelitian ini standart yang dibahas hanya standart tiga yang membahas tentang mahasiswa dan lulusan. Standart ini membahas tentang jumlah total mahasiswa, jumlah mahasiswa regular, jumlah mahasiswa baru, jumlah lulusan, jumlah mahasiswa berdasarakan IPK dan prosentasenya.Selain itu juga membahas jumlah mahasiswa regular tujuh tahun terakhir setiap tahunnya. Dalam pengisian borang akreditasi program studi untuk standart tiga yang membahas tentang profil mahasiswa dan lulusan, program studi sistem informasi Fakultas Teknik Universitas Nusantara PGRI Kediri mengalami kesulitan karena 
data mahasiswa yang semakin bertambah, belum terintegrasi sehingga akan memerlukan waktu yang lama untuk menampilkan jumlah mahasiswa berdasarkan isian borang.

Dari pemaparan masalah di atas, muncul gagasan bagi penulis untuk membuat suatu alat bantu berupa aplikasi OLAP profil mahasiswa dan lulusan yang dapat mengatasi permasalahan tersebut. Alat bantu ini diharapkan dapat mendukung pengisian borang akreditasi program studi standart tiga tentang profil mahasiswa dan lulusan di Universitas Nusantara PGRI Kediri Fakultas Teknik Program studi Sistem Informasi.

Dari Latar Belakang yang telah dijelaskan sebelumnya maka dapat diidentifikasikan permasalahanya adalah proses pengisian borang akreditasi tentang profil mahasiswa dan lulusan mengalami kesulitan karena data mahasiswa yang semakin bertambah, belum terintegrasi sehingga akan memerlukan waktu yang lama untuk menampilkan jumlah mahasiswa berdasarkan isian boring. Dalam melaksanakan perencanaan dan pembuatan sistem yang akan dibuat pada tugas akhir ini, permasalahan yang muncul adalah Bagaimana merancang dan membangun aplikasi OLAP Profil mahasiswa dan lulusan?.

Tujuan dari penelitian ini adalah membuat aplikasi OLAP profil mahasiswa dan lulusan pada Program Studi Sistem Informasi Fakultas Teknik Universitas Nusantara PGRI Kediri. Manfaat dari penelitian ini adalah Program studi Sistem Informasi dapat mengetahui informasi tentang profil mahasiswa dan lulusan serta program studi Sistem Informasi lebih mudah dan cepat dalam pengisian borang akreditasi standart 3 tentang profil mahasiswa dan lulusan.

\subsection{Data Warehouse}

Pada dasarnya Data warehouse adalah databsase dan merupakan pusat data yang dibentuk dari hasil penggabungan dan pengolahan data dari beragam sumber data yang digunakan untuk keperluan pelaporan dan analisis data [1]. Data warehouse adalah sebuah sistem yang mengambil dan menyatukan data secara periodik dari sistem sumber menuju ke penyimpanan data dimensional atau penyimpanan data normalisasi [2]. Biasanya data yang tersimpan didalamnya merupakan data sejarah (history data) yang digunakan untuk melakukan analisa untuk mendukung proses pengambilan keputusan. Selain itu data diperbarui secara berkelompok bukan setiap saat ketika proses transaksi berjalan pada sistem sumber. Menurut Han dan Kamber (2008), suatu basis data dapat digolongkan sebagai data warehouse jika memiliki karakteristik sebagai berikut :

a. Berorientasi Subjek

Data diorganisasikan oleh subjek secara rinci, misalnya : berdasarkan pelanggan, jenis, dan lainlain.

b. Terintegrasi

Basis data mencakup data dari kebanyakan atau semua aplikasi operasional organisasi dan data tersebut dibuat secara konsisten.

c. Time-Variant

Data tidak menyediakan status saat ini, data tersebut disimpan untuk periode lima atau sepuluh tahun bahkan lebih dan digunakan untuk tren, peramalan, dan perbandingan. Waktu merupakan dimensi penting yang harus didukung oleh semua data warehouse.

d. NonVolatile

Data yang dimasukkan ke dalam data warehouse adalah data yang read-only, yang tidak dapat dirubah. Data yang sudah lama dihapus dan perubahan direkam sebagai data yang baru.

e. Ringkas.

Jika diperlukan, data operasional dimasukkan ke dalam ringkasan data. Dalam data warehouse biasanya tidak dinormalisasi sehingga masih terjadi redudansi atau duplikasi data.

f. Sumber.

Semua sumber data tersedia dalam data warehouse, baik internal maupun eksternal.

g. Metadata

Metadata mengacu pada data tentang data yang menguraikan struktur dan beberapa arti tentang data, dengan demikian mendukung penggunaan yang efektif atau tidak efektif dari data.

\subsection{Online Transactional Processing}

Online Transactional Processing (OLTP) adalah teknologi untuk mengelola aplikasi yang berorientasi pada transaksi [1]. Karena teknologi ini berhubungan dengan database, setiap database yang berhubungan dengan OLTP disebut database OLTP. Database OLTP adalah database yang umum digunakan pada aplikasi yang berorientasi pada transaksi, yaitu aplikasi yang cenderung lebih banyak melakukan proses insert,update dan delete secara real-time dan umumnya ditujukan untuk aplikasi yang tergolong mission 
critical application, yaitu aplikasi yang jika terjadi masalah atau gangguan bisa menyebabkan proses bisnis terganggu.

\subsection{OnLine Analytical Processing}

OnLine Analytical Processing (OLAP) adalah teknologi untuk menjawab kebutuhan analitik [1]. Seperti juga OLTP, OLAP berhubungan dengan database. Setiap database yang berhubungan dengan OLAP disebut database OLAP. Database OLAP adalah database yang dimaksimalkan untuk kecepatan dalam pembacaan (select query). OLAP mengandung dua tipe dasar, yaitu measures dan dimension. Measures adalah data bilangan yang terukur,misalkan kuantitas(quantity), harga(price), nilai rata-rata(averages) dari kelompok nilai tertentu, jumlah(sum) dari kelompok nilai tertentu. Dimension mengacu pada kategori yang digunakan untuk mengatur measures. Biasanya data dikelompokkan dalam bentuk bertingkat(level). Dimensi yang umumnya hampir selalu ada adalah dimensi waktu(time dimension). Pada dimensi ini, hierarki yang disusun biasanya tahun, kuartal, bulan dan hari. Bisa juga jika diperlukan ada minggu di antara bulan dan hari. OLAP merupakan perpaduan dinamis analisis dan gabungan dari data multi dimensional dalam jumlah yang besar [3]. OLAP merupakan kumpulan aturan yang menyediakan sebuah kerangka dimensional untuk mendukung pengambilan keputusan. OLAP juga merupakan sebuah pendekatan secara cepat menyediakan jawaban-jawaban terhadap query analitik yang multi dimensi. OLAP adalah bagian dari kategori yang lebih global dari pemikiran bisnis, yang juga merangkum hubungan antara pelaporan dan penggalian data. Di dalam inti sebaran sistem OLAP merupakan konsep dari sebuah kubus OLAP (disebut juga sebagai kubus multi dimensi atau hyper cube) yang terdiri dari numeric fact yang disebut ukuran dan dikategorikan sebagai dimensi. Kubus metadata secara khusus terbuat dari sebuah skema bintang atau skema kristal salju dari tabel di dalam sebuah Database yang berhubungan. Ukuran diturunkan dari rekord dalam fact table dan dimensi-dimensi yang diturunkan dari tabel-tabel dimensi. Dengan menggunakan metode $O L A P$, data-data yang terkait dengan kondisi lulusan institusi pendidikan dapat dikumpulkan kedalam suatu data warehouse. Data warehouse ini berfungsi sebagai sumber data untuk menghasilkan informasi histori lulusan, sehingga pihak manajemen dapat memanfaatkan informasi tersebut sebagai bahan dalam pengambilan keputusan, agar peningkatan kompetensi lulusan selalu menghasilkan pencapaian maksimal [4]. Pembangunan aplikasi OnLine Analytical Processing (OLAP) Data Warehouse merupakan salah satu cara untuk mengekstrak informasi penting dari beberapa sistem informasi yang berbeda. Di mana data yang sudah terintegrasi dapat dimanfaatkan untuk kegiatan penyampaian informasi yang dapat ditinjau dari berbagai sudut pandang atau dimensi dan dapat diatur tingkatan rincian datanya[5].

\subsection{Data Staging}

Data staging menyediakan sebuah tempat dengan satu set fungsi untuk membersihkan, mengubah, menggabungkan, mengkonversi, mencegah duplikasi data, dan menyiapkan data sumber untuk penyimpanan dan penggunaan dalam data warehouse. Tahap pembersihan ini dikenal juga dengan istilah Extract, Transformation and Loading (ETL)[6].

\subsection{Extract, Transform, Load}

Exctract,Transform Load (ETL) adalah sekumpulan proses untuk mengambil dan memproses data dari satu atau banyak sumber menjadi sumber baru [1]. Sumber bisa dari beberapa sumber data, tidak hanya dari OLTP saja, bisa juga dari website, file teks, spreadsheet dan lain sebagainya. Extract adalah suatu proses yang mengidentifikasi seluruh sumber data yang relevan dan kemudian mengambil data dari sumbersumber data tersebut[7]. Proses extract contohnya membaca file dari excel, dari database dan lain-lain. Transform adalah suatu proses yang memiliki peran dalam melakukan perubahan dan integrasi skema data serta struktur yang berbeda ke dalam skema dan struktur yang telah didefinisikan sebelumnya oleh data warehouse. Fungsi-fungsi dalam proses transform dapat berupa pemindahan data, validasi data sesuai aturan yang ditetapkan, modifikasi ( isi, tipe atau struktur data), integrasi atau penggabungan data dari sumber-sumber lain,perhitungan dan lain sebagainya. Load adalah proses pemindahan data secara fisik dari system operasional ke dalam data warehouse. Contoh proses load adalah proses transform yang kemudian disimpan ke database OLAP.

\section{METODOLOGI PENELITIAN}

Penelitian ini dilaksanakan melalui 4 ( empat ) proses, sebagai berikut :

a. Tahap Analisa Pada tahap ini, dilakukan analisa dan pemecahan masalah dalam pembuatan program aplikasi dengan mencari informasi-informasi tentang profil mahasiswa dan lulusan di program studi sistem informasi Universitas Nusantara PGRI Kediri. Sumber lain didapatkan dari internet berupa jurnal dan dari buku- buku yang berkaitan dengan penelitian ini. 
b. Tahap Perancangan, Pada tahap ini peneliti membuat rancangan dan tampilan aplikasi $O L A P$ yang akan digunakan.

c. Tahap Uji Coba, Pada tahap ini, peneliti melakukan uji coba dan evaluasi tampilan dan cara kerja aplikasi OLAP yang akan diimplemtasikan di sistem operasi Windows.

d. Tahap Implementasi, Pada tahap ini akan dilakukan pengimplementasian hasil rancangan dengan menggunakan program Embarcadero Delphi 10.2 Tokyo dengan database MySQL

\section{HASIL DAN PEMBAHASAN}

\subsection{Proses Extract}

Program studi Sistem Informasi Universitas Nusantara PGRI Kediri dalam mengolah data nilai mahasiswa dilakukan oleh dosen dengan menggunakan format excel. Setiap dosen yang mengampu matakuliah tertentu mengikuti format pengisian nilai yang telah disediakan oleh program studi. Format excel yang telah diisi nilai oleh dosen kemudian diserahkan kembali kepada petugas admin program studi. Contoh data nilai mahasiswa dalam format excel ditunjukkan pada gambar 1

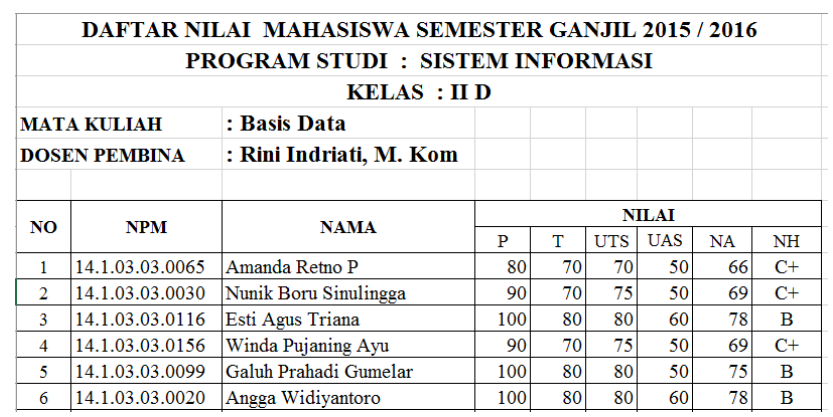

Gambar 1. Contoh Data Nilai Mahasiswa Dalam Format Excel

Gambar 1 menunjukkan contoh format nilai mahasiswa yang telah diisi oleh dosen pengampu setiap matakuliah. Data nilai mahasiswa dalam format excel terdapat data kelas, nama matakuliah, nama dosen Pembina , tabel nilai yang berisi no, NPM, nama mahasiswa, nilai presensi(P), nilai tugas(T), nilai ujian tengah semester(UTS), nilai ujian akhir semester(UAS), nilai akhir(NA) yang diperoleh dari perhitungan semua data sesuai kebijakan program studi dan nilai huruf berdasarkan range nilai akhir(NA) yang telah dihitung sebelumnya. Langkah berikutnya adalah melakukan proses extract dari data nilai mahasiswa dari gambar 1. Hasil proses extract ditunjukkan dalam gambar 2.

\begin{tabular}{r|l|l|l|l|} 
No. & \multicolumn{1}{|c|}{ NPM } & \multicolumn{1}{|c|}{ Nama mahasiswa } & NILAI HURUF & kode_mk \\
\hline 1 & 14.1 .03 .03 .0065 & Amanda Retno P & C+ & MKK-2004 \\
\hline 2 & 14.1 .03 .03 .0030 & Nunik Boru Sinulingga & C+ & MKK-2004 \\
\hline 3 & 14.1 .03 .03 .0116 & Esti Agus Triana & B & MKK-2004 \\
\hline 4 & 14.1 .03 .03 .0156 & Winda Pujaning Ayu & C+ & MKK-2004 \\
\hline 5 & 14.1 .03 .03 .0099 & Galuh Prahadi Gumelar & B & MKK-2004 \\
\hline 6 & 14.1 .03 .03 .0020 & Angga Widiyantoro & B & MKK-2004 \\
\hline
\end{tabular}

\section{Gambar 2. Hasil Proses Extract Data Nilai Mahasiswa}

Gambar 2 menunjukkan hasil proses extract dari gambar 1. Hasil proses extract data nilai mahasiswa terdapat data no, NPM, nama mahasiswa, nilai huruf dan kode_mk. Proses extract tersebut mengambil nilai huruf dari nilai akhir dari setiap nilai mahasiswa dalam matakuliah dan mengambil kode matakuliah (kode_mk) sesuai dengan nama matakuliahnya. Langkah berikutnya adalah melakukan proses extract untuk grade nilai matakuliah. Grade dibutuhkan untuk mengetahui konversi nilai dari setiap matakuliah. Hasil proses extract grade nilai ditunjukkan pada gambar 3 .

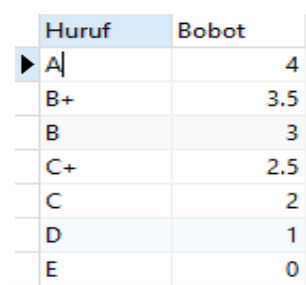

Gambar 3. Hasil Proses Extract Grade Nilai 
Gambar 3 menunjukkan hasil proses extract grade nilai. Hasil proses extract grade nilai ditampilkan huruf beserta bobotnya. Range nilai yang digunakan mulai A dengan bobot 4 sampai dengan E dengan bobot 0 . Langkah berikutnya adalah melakukan proses extract untuk data matakuliah. Sks dalam data matakuliah dibutuhkan untuk menentukan pembagi dari total indeks prestasi mahasiswa. Contoh hasil proses extract data matakuliah ditunjukkan pada gambar 4.

\begin{tabular}{l|l|l|l}
\hline KODE_MK & MATA_KULIAH & SKS & semester \\
\hline MPK - 1003 & ke-PGRI-an & 2 & 1 \\
\hline MKK - 2006 & Konsep Sistem Informasi & 4 & 1 \\
\hline MKK - 2001 & Logika dan Algoritma & 4 & 1 \\
\hline MKK - 2005 & Dasar Akuntansi & 4 & 1 \\
\hline MKK - 2002 & Aljabar Linear & 2 & 1 \\
\hline MKK - 2015 & Statistik & 2 & 1 \\
\hline MKK - 2012 & Pengantar Manajemen & 2 & 1 \\
\hline MPK - 1001 & Bahasa Inggris & 2 & 2 \\
\hline MPK - 1006 & Pancasila \& Kewarganegarai & 3 & 2 \\
\hline MKK - 2016 & Sistem Operasi & 2 & 2 \\
\hline MKK - 2013 & Sistem Informasi Manajeme & 2 & 2 \\
MKK - 2010 & Matematika Diskret & 2 & 2
\end{tabular}

\section{Gambar 4. Contoh Hasil Proses Extract Data Matakuliah}

Gambar 4 menunjukkan contoh hasil proses extract data matakuliah. hasil proses extract ditampilkan matakuliah ada data kode matakuliah, nama matakuliah,sks dan semester. Indeks prestasi komulatif dihitung dari jumlah sks dikalikan dengan bobot nilai sesuai grade kemudian dibagi dengan jumlah sks matakuliah yang telah diambil. Langkah berikutnya adalah proses extract data lulusan yang akan dihitung indeks prestasi komulatifnya. Contoh hasil extract data lulusan ditunjukkan dalam tabel 5.

\begin{tabular}{|c|c|c|c|c|}
\hline $\mathrm{npm}$ & nama & Thn_Akademik & tahun_masuk & Ket \\
\hline 07.1 .03 .03 .0002 & CINDY SIMBARA & 2010/2011 & 2007 & ts -5 \\
\hline 07.1 .03 .03 .0003 & M. NAJIBULLOH MUZAKI & 2010/2011 & 2007 & ts -5 \\
\hline $07.1 \cdot 03 \cdot 03.0004$ & RIZKI ARIF FAUZI & 2010/2011 & 2007 & ts -5 \\
\hline 08.1.03.03.0005 & DESYNTA MEGA DEWI & 2012/2013 & 2008 & ts -3 \\
\hline 08.1.03.03.0007 & HENDRA PANJI PERMANA & 2012/2013 & 2008 & ts -3 \\
\hline 08.1.03.03.0008 & INTAN RAMADHAN & 2012/2013 & 2008 & ts -3 \\
\hline 08.1 .03 .03 .0009 & LILIS SETYONINGSIH & 2012/2013 & 2008 & ts -3 \\
\hline 08.1.03.03.0011 & MOH. HAFIDH ALUFIAN & 2012/2013 & 2008 & ts -3 \\
\hline 08.1.03.03.0013 & NURUL HASANAH & 2012/2013 & 2008 & ts -3 \\
\hline 08.1.03.03.0014 & REBECCA MAULINA HANIF $/$ & 2012/2013 & 2008 & ts -3 \\
\hline 08.1.03.03.0015 & RIZKY ANDA SWARDANI & 2012/2013 & 2008 & ts -3 \\
\hline 08.1.03.03.0016 & TRI YUDHITA W & 2012/2013 & 2008 & ts -3 \\
\hline 08.1.03.03.0017 & YUNITA EFI LESTARI & $2012 / 2013$ & 2008 & ts -3 \\
\hline
\end{tabular}

Gambar 5. Contoh Hasil Extract Data Lulusan

Gambar 5 menunjukkan contoh hasil proses extract data lulusan. Hasil proses extract data lulusan ditampilkan data NPM, nama mahasiswa, tahun akademik, tahun masuk dan keterangan tahun sekarang(TS).

\subsection{Proses Transform}

Langkah berikutnya adalah proses transform. Proses transform dilakukan untuk perubahan dan integrasi data yang telah didapatkan dari proses extract. Proses transform yang dibutuhkan dalam penelitian ini adalah untuk menghitung indeks prestasi komulatif(IPK). Proses transform dilakukan dengan cara mengintegrasikan data lulusan,data matakuliah, grade nilai dan nilai mahasiswa yang disimpan dalam tabel data_nilai. Contoh hasil proses transform IPK ditunjukkan dalam gambar 6

\begin{tabular}{|c|c|c|c|}
\hline NPM & Nilai_huruf & Kode_MK & Bobot \\
\hline 13.1 .03 .03 .0002 & A & MKB-3010 & 4 \\
\hline 13.1 .03 .03 .0002 & $\mathrm{~B}+$ & MKB-3011 & 3.5 \\
\hline 13.1 .03 .03 .0002 & $\mathrm{~B}^{+}$ & MKB-3012 & 3.5 \\
\hline 13.1 .03 .03 .0002 & A & MKB-3015 & 4 \\
\hline 13.1 .03 .03 .0002 & $\mathrm{c}+^{+}$ & MKB-3016 & 2.5 \\
\hline 13.1 .03 .03 .0002 & A & MKB-3017 & 4 \\
\hline 13.1 .03 .03 .0002 & A & MKB-3018 & 4 \\
\hline 13.1 .03 .03 .0002 & $\mathrm{~B}+$ & MKB-3019 & 3.5 \\
\hline 13.1 .03 .03 .0002 & $\mathrm{~B}+$ & MKB-3020 & 3.5 \\
\hline 13.1 .03 .03 .0002 & $\mathrm{C}_{+}$ & MKB-3027 & 2.5 \\
\hline 13.1 .03 .03 .0002 & B & MKB-3029 & 3 \\
\hline 13.1 .03 .03 .0002 & B & MKB-3030 & 3 \\
\hline 13.1 .03 .03 .0002 & B & MKB-3031 & \\
\hline
\end{tabular}

Gambar 6. Contoh Hasil Proses Transform IPK 
Gambar 6 menunjukkan contoh hasil proses transform IPK. Hasil proses transform IPK menampilkan data NPM, nilai_huruf, kode_mk(kode matakuliah) dan bobot. Proses menghitung IPK diperlukan jumlah sks sebagai pembaginya. Langkah berikutnya adalah membuat function untuk menghitung jumlah sks lulusan. Function menghitung jumlah sks lulusan ditunjukkan pada gambar 7.

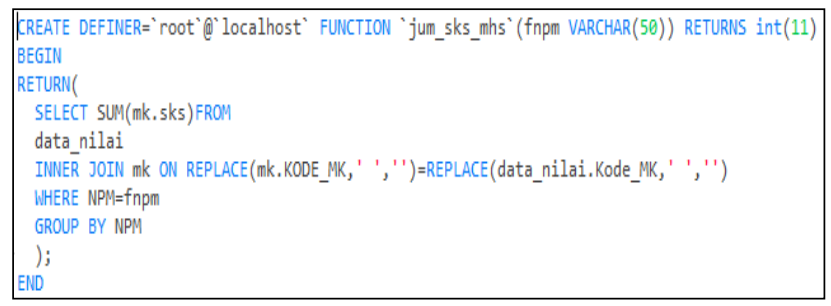

Gambar 7 Function Untuk Menghitung Jumlah Sks Lulusan.

Gambar 7 menunjukkan function untuk menghitung jumlah sks lulusan yang digunakan untuk menghitung IPK lulusan. Langkah berikutnya adalah dibuat function untuk menghitung IPK. Function untuk menghitung IPK ditunjukkan pada gambar 8.

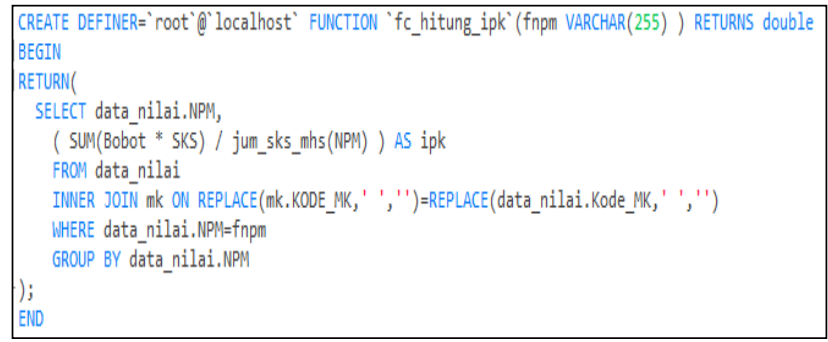

\section{Gambar 8 Function Untuk Menghitung IPK Lulusan}

Gambar 8 menunjukkan function untuk menghitung IPK lulusan. Data diambil dari data_nilai (hasil proses transform) pada gambar 6. Contoh hasil dari perhitungan IPK lulusan ditunjukkan pada gambar 9

\begin{tabular}{|l|r|}
\hline NPM & ipk \\
\hline 12.1 .03 .03 .0382 & 3.19 \\
\hline 12.1 .03 .03 .0358 & 3.42 \\
\hline 12.1 .03 .03 .0321 & 3.37 \\
\hline 12.1 .03 .03 .0390 & 3.19 \\
\hline 12.1 .03 .03 .0279 & 3.12 \\
\hline 12.1 .03 .03 .0044 & 3.35 \\
\hline 12.1 .03 .03 .0394 & 3.4 \\
\hline 12.1 .03 .03 .0024 & 3.26 \\
\hline 12.1 .03 .03 .0213 & 3.32 \\
\hline 12.1 .03 .03 .0273 & 3.33 \\
\hline 12.1 .03 .03 .0207 & 3.25 \\
\hline
\end{tabular}

\section{Gambar 9 Contoh Hasil Perhitungan IPK Lulusan}

Gambar 9 menunjukkan contoh hasil perhitungan IPK. Hasil perhitungan IPK lulusan menampilkan NPM lulusan dan IPK. Langkah berikutnya adalah proses transform untuk menampilkan IPK minimum, IPK rata-rata dan IPK maksimum. Query untuk menampilkannya ditunjukkan pada gambar 10.

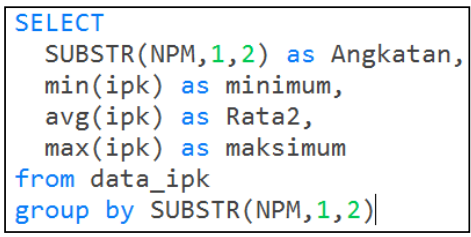

\section{Gambar 10. Query IPK Minimum,Rata-Rata dan Maksimum}

Gambar 10 menunjukkan query untuk menampilkan IPK minimum,rata-rata dan maksimum. Hasil dari query pada gambar 10 akan digunakan untuk mengisi IPK lulusan berdasarkan angkatan, IPK minimum, IPK rata-rata dan IPK maksimum. 


\subsection{Proses Load}

Langkah berikutnya adalah proses load. Proses load dalam penelitian ini dilakukan langkah untuk memasukkan data ke tabel fakta prosentase IPK. Procedure untuk memasukkan data ke tabel fakata prosentase IPK ditunjukkan dalam gambar 11.

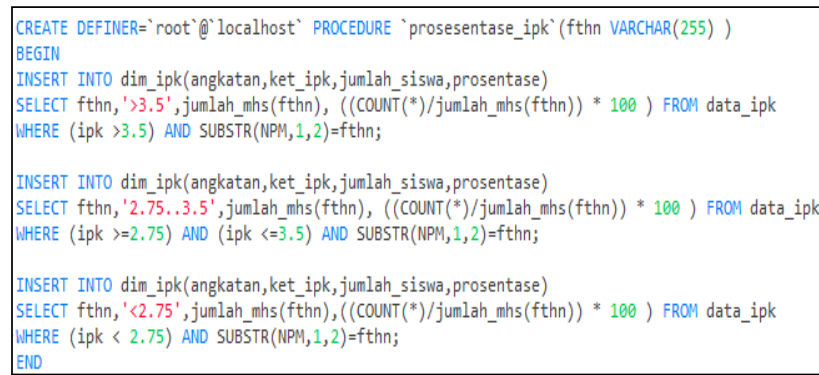

\section{Gambar 11. Procedure Untuk Memasukkan Data Ke Tabel Fakata Prosentase IPK}

Gambar 11 menunjukkan Procedure untuk memasukkan data ke tabel fakata prosentase IPK. Procedure tersebut digunakan untuk pengelompokkan prosentase IPK mulai dari nilai IPK di bawah 2,75, nilai IPK antara 2,75 sampai 3,5 dan nilai IPK di atas 3,5. Hasil dari eksekusi procedure dari pada gambar 11 ditunjukkan pada gambar 12.

\begin{tabular}{|l|l|l|r|}
\hline angkatan & ket_ipk & jumlah & prosentase \\
\hline 12 & $<2.75$ & 0 & 0 \\
\hline 12 & 2.75 .3 .5 & 93 & 90.2913 \\
12 & $>3.5$ & 10 & 9.70874 \\
\hline 13 & $<2.75$ & 71 & 54.1985 \\
13 & $2.75 . .3 .5$ & 55 & 41.9847 \\
13 & $>3.5$ & 5 & 3.81679 \\
14 & $<2.75$ & 90 & 50 \\
14 & 2.75 .3 .5 & 75 & 41.6667 \\
14 & $>3.5$ & 15 & 8.33333 \\
16 & $<2.75$ & 9 & 28.125 \\
16 & 2.75 .3 .5 & 20 & 62.5 \\
16 & $>3.5$ & 3 & 9.375 \\
\hline
\end{tabular}

\section{Gambar 12.Hasil Dari Eksekusi Procedure Sebagai Proses Load}

Gambar 12 menunjukkan hasil eksekusi Procedure sebagai proses load yang digunakan untuk pengelompokkan prosentase IPK . Hasil pengelompokkan IPK menampilkan data angkatan, ket_ipk(pengelompokkan IPK), jml (jumlah lulusan) dan prosentase.

\subsection{Aplikasi OLAP}

Aplikasi OLAP yang dihasilkan menggunakan hasil dari proses load. Aplikasi dibuat menggunakan Embarcadero Delphi 10.2 Tokyo dengan database MySQL. Tampilan Aplikasi OLAP prosentase IPK lulusan ditunjukkan pada gambar 13 dan Aplikasi OLAP IPK minimum, rata-rata dan maksimum ditunjukkan pada gambar 14 .

\begin{tabular}{|c|c|c|c|}
\hline prosentase $\downarrow$ & ket_ipk $\Delta \square$ & & \\
\hline angkatan $\Delta \downarrow$ & $2.75 . .3 .5$ & $<2.75$ & $>3.5$ \\
\hline 12 & 90.29 & 0.00 & 9.71 \\
\hline 13 & 41.98 & 54.20 & 3.82 \\
\hline 14 & 41.67 & 50.00 & 8.33 \\
\hline 16 & 62.50 & 28.13 & 9.38 \\
\hline
\end{tabular}

\section{Gambar 13.Aplikasi OLAP Prosentase IPK Lulusan}

Gambar 13 menunjukkan aplikasi OLAP prosentase IPK lulusan berdasarkan range IPK yang didapatkan dari hasil proses load pada gambar 12. Aplikasi OLAP prosentase IPK untuk lulusan menampilkan angkatan, pengelompokkan IPK dan prosentase pada setiap angkatan dan pengelompokkan IPK. 


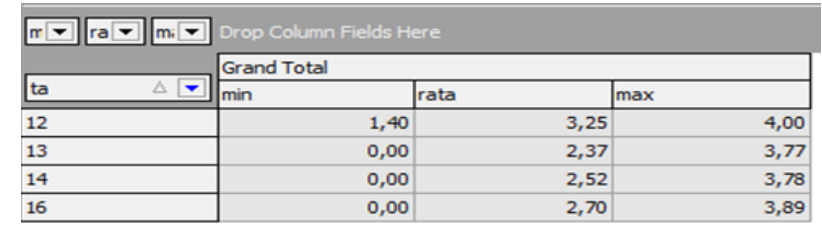

Gambar 14. Aplikasi OLAP IPK Minimum,Rata-Rata Dan Maksimum

Gambar 14 menunjukkan aplikasi OLAP IPK minimum,rata-rata dan maksimum yang didapatkan dari hasil proses load. aplikasi OLAP IPK minimum,rata-rata dan maksimum menunjukkan tahun angkatan(ta), IPK minimum(min), IPK rata-rata(rata) dan IPK maksimum(max).

\subsection{Pembahasan}

Aplikasi OLAP yang telah dihasilkan dapat digunakan untuk membantu Program Studi Sistem Informasi Fakultas Teknik Universitas Nusantara PGRI Kediri dalam pengisian borang akreditasi program studi untuk standart tiga yang membahas tentang profil mahasiswa dan lulusan. Aplikasi OLAP yang telah dihasilkan adalah aplikasi $O L A P$ prosentase IPK lulusan berdasarkan range IPK dan aplikasi OLAP IPK minimum,rata-rata dan maksimum. Aplikasi OLAP IPK membutuhkan data - data dari Program Studi Sistem Informasi Fakultas Teknik Universitas Nusantara PGRI Kediri yang telah diproses menggunakan ETL.

\section{KESIMPULAN}

Berdasarkan pembahasan di atas diambil beberapa kesimpulan, yaitu :

a. Penerapan metode ETL sangat dibutuhkan dalam pembuatan aplikasi OLAP.

b. Proses ETL menggunakan data dari file excel kemudian diolah dan disimpan ke data warehouse OLAP.

c. Dengan adanya aplikasi OLAP IPK lulusan ini bisa membantu pihak program studi sistem informasi dalam pengisian IPK lulusan di standart 3 profil mahasiswa dan lulusan.

d. Dengan adanya data warehouse suatu perguruan tinggi mempunyai kemudahan untuk mendapatkan informasi yang bersifat analisa untuk data mahasiswa dan lulusan.

\section{UCAPAN TERIMA KASIH}

Penelitian ini dapat dilakukan dengan pendanaan penelitian stimulus Yayasan Pembina Lembaga Pendidikan Perguruan Tinggi PGRI Kediri.

\section{DAFTAR PUSTAKA}

[1] M. JRP, 2014. Pentaho : Solusi Open Source untuk Membangun Data Warehouse, 1st ed. Yogyakarta: ANDI Yogyakarta.

[2] V. Rainardi, 2007. Building Data Warehouse With Examples in SQL Server. New York: Apress.

[3] T. M. Connolly and C. E. Begg, 2010. Database Systems: A Practical Approach to Design, Implementation and Management, 5th ed. Pearson.

[4] L. A. Ndoloe, 2012. "Sistem Informasi Lulusan Dengan Metode Online Analitycal processing (OLAP) Pada Politeknik Negeri Kupang," Sist. Inf. Bisnis, vol. 1, no. 2, p. 84.

[5] A. Supriyatna, 2016. "SISTEM ANALISIS DATA MAHASISWA MENGGUNAKAN APLIKASI ONLINE ANALYTICAL PROCESSING (OLAP) DATA WAREHOUSE,” Pilar Nusa Mandiri, vol. XII, no. 1, p. 62.

[6] S. P. Adithama, I. Wisnubhadra, and B. L. Sinaga, 2013. "ANALISIS DAN DESAIN REAL-TIME BUSINESS INTELLIGENCE UNTUK SUBJEK KEGIATAN AKADEMIK PADA UNIVERSITAS MENGGUNAKAN CHANGE DATA CAPTURE," in Seminar Nasional Teknologi Informasi dan Komunikasi.

[7] M. Y. Pusadan, 2013. Rancang Bangun Data Warehouse, 1st ed. Yogyakarta: Graha Ilmu. 